\title{
UNVIABLE FERAL CAT POPULATION RESULTS IN ERADICATION SUCCESS ON WEDGE ISLAND, TASMANIA
}

\author{
by Susan Robinson and Luke Gadd
}

(with one text-figure and one table)

\begin{abstract}
Robinson, S. \& Gadd, L. 2020 (9:xii): Unviable feral cat population results in eradication success on Wedge Island, Tasmania. Papers and Proceedings of the Royal Society of Tasmania 154: 47-50. https://doi.org/10.26749/rstpp.154.47 ISSN: 0080-4703. Biosecurity Tasmania, 13 St Johns Avenue, New Town, Tasmania 7008, Australia (SR*); Tasmania Parks and Wildlife Service, Mt Field National Park, 66 Lake Dobson Road, National Park, Tasmania 7140, Australia (LG). *Author for correspondence. Email: sue.robinson@dpipwe.tas.gov.au

Wedge Island in southeast Tasmania is 43 ha in size and is habitat for Little Penguin (Eudyptula minor) and Short-tailed Shearwater (Ardenna tenuirostris) populations. The island was subject to a feral Cat (Felis catus) eradication attempt in 2003 when 13 cats were captured with the assistance of trained detection dogs. It was known at least one cat remained. No further cats were captured during two subsequent visits in 2003 and 2004 and a single dead cat was found in 2012. It appeared the cat population never recovered from the initial knockdown and this ultimately resulted in eradication success. Methods used and details of cats caught are provided and the program is discussed in terms of criteria required for a successful eradication.
\end{abstract}

Key Words: island eradication, feral Cat, Felis catus, eradication criteria, Tasmania.

\section{INTRODUCTION}

Like other islands of the world, Tasmania's offshore islands have been subjected to deliberate and inadvertent introductions of non-native vertebrates, typically rats (Rattus rattus or $R$. norvegicus), House Mouse (Mus musculus), European Rabbit (Oryctolaguscuniculus) and Cat (Felis catus). Cats have been taken to islands by residents as companion animals and to control pest rodents that have established after arriving in cargo; rabbits have historically been introduced to islands as a food source for fishers, residents and mariners.

Around $10 \%$ of Tasmania's 600 vegetated islands and islets are recorded as having vertebrate pests and at least 20 islands have had cats introduced. Feral cats were eradicated from two islands in the Furneaux Group (Little Green and Great Dog) in the 1980s (Campbell et al. 2011), from subantarctic Macquarie Island in 2000 (Robinson \& Copson 2014) and from Tasman Island in 2010 (Robinson et al. 2015). After the Macquarie Island cat eradication monitoring period concluded in 2002, staff, traps and cat detection dogs became available for use on further projects. The removal of feral cats from Wedge Island, southeast Tasmania, was attempted in 2003 with support from the Marine Conservation Program, Department of Primary Industries, Parks, Water and Environment (Tasmania).

European Rabbit and Sheep (Ovis aries) were introduced to Wedge Island in 1930 by fishers (N. Brothers quoted in Beh 1995). Rabbits outcompeted the sheep for food, so the sheep were removed in 1939. Cats were first recorded on the island in 1939 and were probably introduced for rabbit control. It appears these cats died out some years later (Beh 1995). Sheep were then returned to the island at a subsequent unknown date prior to 1970. Myxoma virus was released on Wedge Island through the 1970s, and in 1976 cats were re-introduced (apparently one pregnant female) to help control the rabbits that were again impacting vegetation and sheep grazing (Beh 1995). The rabbits died out around 1978 and the sheep were removed in 1986 but cats remained (Beh 1995). No rodents or other introduced mammals are present on the island, leaving seabirds as the main food source for cats.

\section{STUDY SITE}

Wedge Island ( $\left.43^{\circ} 08^{\prime} \mathrm{S}, 147^{\circ} 40^{\prime} \mathrm{E}\right)$, located on the western side of the Tasman Peninsula, was reserved as a Conservation Area in 2004 and is $800 \mathrm{~m}$ in distance from the closest point to mainland Tasmania. Orientated north-south, Wedge Island is approximately 1.3 by $0.6 \mathrm{~km}$ with an area of 43 ha. The island has steep dolerite cliffs on the western side tapering to a rocky shoreline in the east. The island rises to $96 \mathrm{~m}$. Tussock Grass (Poa poiformis) and Saggs (Lomandra longifolia) are the dominant vegetation with patches of succulents (Carpobrotus rossii), Kangaroo Apple (Solanum laciniatum) and a small remnant eucalypt (Eucalyptus viminalis) and she-oak (Casurina sp.) woodland (Brothers et al. 2001).

The island has a significant seabird fauna, including 12,000 pairs of Short-tailed Shearwaters (Ardenna tenuirostris) and 1000 pairs of Little Penguin (Eudyptula minor) (Brothers et al. 2001, Vertigan 2010). Other vertebrates include the Tasmanian Native Hen (Gallinula mortierri) and two species of skink (Niveoscincus metallicus and N. ocellatus). Fairy Prions (Pachyptila turtur) are believed to have been breeding on the island up to the 1970s (N. Brothers quoted in Beh 1995). Fur seals (Arctocephalus pusillus and $A$. forsteri) are present on the coastal rock platform.

\section{METHODS}

Field teams of two people camped on the island three times during 2003 and 2004. Methods available to capture cats 
were wire mesh drop-door cage traps $(600 \times 300 \times 300$ $\mathrm{mm}$ ) (Mascot Wireworks, Preston, Victoria), rubber-jawed leg-hold traps (Victor, no. 3: Woodstream Corp. Lititz, PA, USA) and shooting with a .22 calibre rifle under spotlight or when located by trained cat detection dogs.

Brief visits to the island to check for cat signs (footprints in sand or scats, etc.) were made opportunistically from 2007 to 2010. Four remote sensing cameras (Scoutguard SG-550) were installed on the island for four weeks during September and October 2008 and nine Reconyx Hyperfire remote sensing cameras from January to April 2012 and again from May to July 2012. Whilst land managers were generally confident no cats remained from 2012 onwards, the availability of a cat detection dog facilitated an additional final check for cat sign in 2019.

\section{RESULTS}

The effort to eradicate and monitor the cat population on Wedge Island is summarised in table 1. A primary knockdown of 14 days in 2003 was followed by 12 days of further effort but this was insufficient to capture the last cat/s. The project was unable to gain additional investment support for several years. In 2003, 13 cats were captured and at least one cat was known to remain giving a population of at least 14 individuals. At least one cat was known to be present until December 2010. This cat likely died in late 2011 and its body was found in May 2012.

Thirteen cats were captured in 2003: seven adult males (mean $4.1 \pm$ SD $0.3 \mathrm{~kg}, \mathrm{n}=7$ ), five adult females (mean $2.9 \pm \mathrm{SD} 0.6 \mathrm{~kg}, \mathrm{n}=4$ ) and one juvenile female in poor condition $(1.1 \mathrm{~kg})$. Of these cats, 12 were white with patches of tabby, tortoise-shell or black, and a single animal had a solid tabby pelage. Three of the males had very worn teeth and one had a tattooed ear from the Beh (1995) study. The cat found dead in 2012 was a tabby.

For the first island visit (21 July to 4 Aug 2003) cage traps and leg-hold traps were set for cats. No cats were caught in either trap type. All cats captured over this 14day period were located in seabird burrows as indicated by two detection dogs (fig. 1). Burrows were dug open by hand and cats humanely euthanised with a .22 calibre rifle. A second visit (27 Aug to 4 Sep 2003) was unsuccessful in capturing cats. Cat prints in sand and a freshly killed Little Penguin were recorded. During a four-day field trip in winter 2004, cat sign was again found (prints, scent and scats) but no capture resulted.

Stomach contents from cats euthanised in 2003 mostly contained remains of Little Penguins, including body parts of small chicks and adults. In July 2003, Little Penguins were incubating eggs or recently hatched young. Fish was present in cat diet and could have been from penguin stomachs or scavenged from the shoreline. Invertebrates were also present (beetles and caterpillars, species not identified).

With the total number of cats being at least 14 individuals in 2003, the density for Wedge Island was around 0.33 cats per ha. From the detailed field notes of Nigel Brothers in 1984 (State Library of Tasmania Archives), 15 to 17 individual cats could be identified for Wedge Island, 12 of which were trapped and tagged over 12 days in July and August 1984 as part of an unpublished energetics study. The ecological study by Beh in 1995 estimated "not more than a total of 15 individuals (cats) on the island".

TABLE 1 - Visits to Wedge Island: eradication effort and cat sign recorded from 2003 to 2019.

\begin{tabular}{|c|c|c|c|c|c|c|c|c|c|}
\hline \multirow[t]{2}{*}{ Trip date } & \multirow{2}{*}{$\begin{array}{l}\text { Trip } \\
\text { days }\end{array}$} & \multirow{2}{*}{$\begin{array}{l}\text { Staff } \\
\text { days }\end{array}$} & \multirow{2}{*}{$\begin{array}{l}\text { Dog } \\
\text { days }\end{array}$} & \multicolumn{2}{|c|}{ Trap nights } & \multirow{2}{*}{$\begin{array}{l}\text { Spotlight } \\
\text { hours }\end{array}$} & \multirow{2}{*}{$\begin{array}{c}\text { Camera } \\
\text { nights }\end{array}$} & \multirow[t]{2}{*}{ Cats } & \multirow[t]{2}{*}{ Comments } \\
\hline & & & & Cage & Leg-hold & & & & \\
\hline $21 \mathrm{Jul} 03$ & 14 & 14 & 28 & 273 & 210 & 30 & - & 13 dead & At least 1 cat (tabby) remaining \\
\hline 27 Aug 03 & 9 & 9 & 18 & 45 & 75 & 24 & - & - & $\begin{array}{l}\text { Cat scent detected by dogs; cat prints and } \\
\text { scats }\end{array}$ \\
\hline 29 Jun 04 & 4 & 4 & 8 & 12 & 60 & 12 & - & - & $\begin{array}{l}\text { Cat scent detected by dogs; cat prints and } \\
\text { scats }\end{array}$ \\
\hline 7 Sep 07 & 0.25 & 0.25 & - & - & - & - & - & - & Cat prints \\
\hline 5 Sep 08 & 1 & 0.5 & - & - & - & - & 160 & - & $\begin{array}{l}\text { Cat prints and scats; no cats recorded on } \\
\text { cameras }\end{array}$ \\
\hline 23 Aug 10 & 0.25 & 0.25 & - & - & - & - & - & - & Cat prints \\
\hline 17 Dec 10 & $\approx 20$ & - & - & - & - & - & - & 1 live & $\begin{array}{l}\text { Tabby. Observation by University of } \\
\text { Tasmania }\end{array}$ \\
\hline 23 Jan 12 & 1 & 3 & 1 & - & - & - & - & - & 2 old scats. No fresh scent located by dog \\
\hline 11 Apr 12 & 1 & 1 & - & - & - & - & 711 & - & No cats recorded on cameras \\
\hline 31 May 12 & 1 & 7 & 1 & - & - & - & - & 1 dead & $\begin{array}{l}\text { Tabby, desiccated; no fresh scent located } \\
\text { by dog }\end{array}$ \\
\hline 13 Jul 12 & 1 & 1 & - & - & - & - & 344 & - & No cats recorded on cameras \\
\hline 27 Sep 19 & 1 & 1 & 1 & - & - & - & - & - & No sign of cats found \\
\hline
\end{tabular}




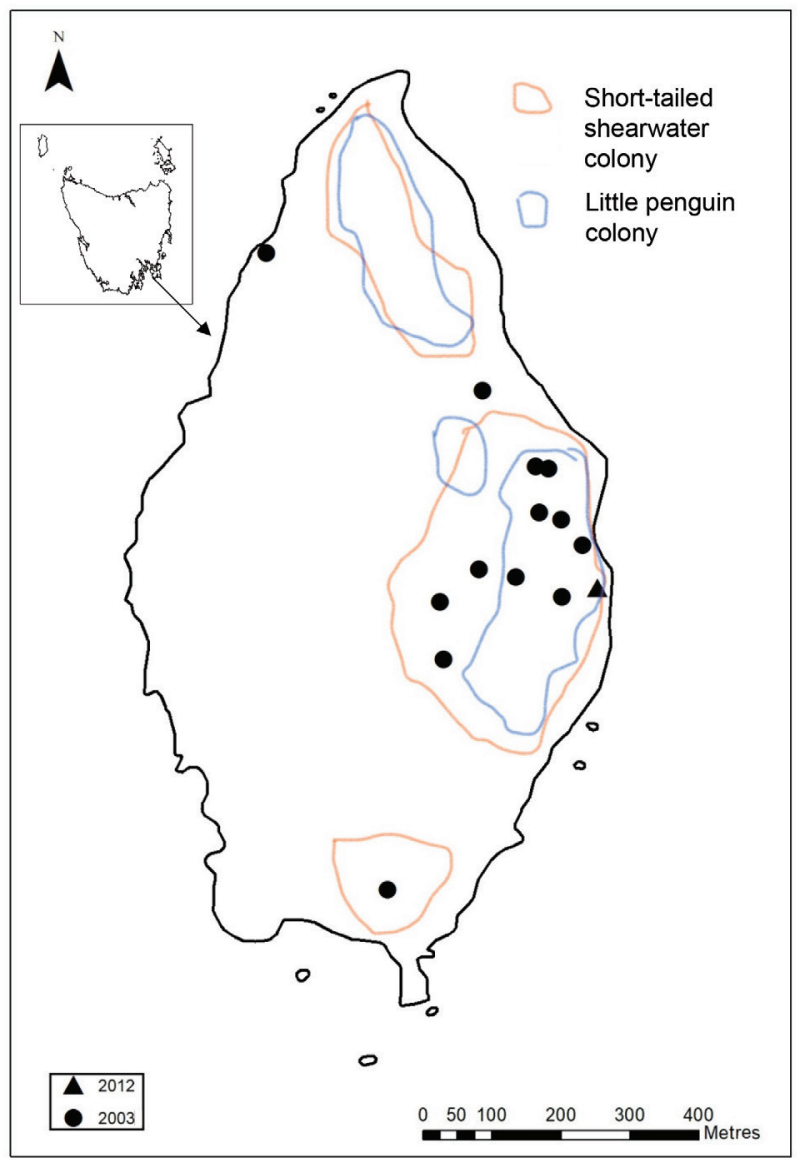

FIG. 1 - Map of Wedge Island, southeast Tasmania, showing locations of cats caught in 2003 (dots) and found dead in 2012 (triangle); seabird distribution is from Beh (1995) and Vertigan (2010).

\section{DISCUSSION}

In 2003, it was likely the Wedge Island cat population was reduced to either one cat or to a low number of cats of the same sex. This outcome left the cat population unviable and it died out in 2011. In 2012, with the establishment of the 'Invasive Species Branch' as part of Biosecurity Tasmania, it was decided to finalise the project through monitoring and locating any remaining cats. Camera monitoring and a thorough search of the island with a team of seven people and a cat detection dog found one dead cat that had likely died several months earlier. No other evidence or fresh cat sign has been found since.

The most effective method of locating cats on Wedge Island was with cat detection dogs indicating which seabird burrows were occupied by a cat. Interestingly, no cats entered cage or leg-hold traps. Dissected cats showed full stomachs of mostly Little Penguin remains, suggesting food was plentiful in July and why food lures in traps were not effective. Leg-hold traps were set outside the seabird colonies to avoid catching Little Penguins. It appeared that cats were mostly denning and feeding within the seabird colonies thus may have not encountered the leghold traps. It is possible the remaining cat/s retreated to the inaccessible southwest cliffs to avoid the high level of human and dog activity during field trips and thus evaded capture. In hindsight, poison baiting could have helped target remaining cats in the autumn when seabirds are absent and food availability low.

For island-based vertebrate pest eradication attempts to be successful, it is accepted that several criteria need to be met (Bomford \& O'Brien 1995, Clout \& Veitch 2002).

These criteria are:

- Animals must be killed faster than they reproduce;

- All animals can be put at risk by the methods used;

- Immigration is zero;

- Methods are socially acceptable;

- The project has sufficient institutional support and funding.

The Wedge Island cat eradication attempt in 2003-04 was undertaken on a very small budget. After an effective primary knockdown, the follow-up effort and methods were insufficient, or not appropriate, to catch the last individuals (i.e., Criterion 2 was not met). No further funding was available to support the project (i.e., Criterion 5 was not met) after 2004. Cat activity on the island was sporadically monitored over the ensuing eight years, often in addition to boat trips already occurring in the area. Despite the criteria for eradication apparently not being met, the eradication was eventually successful because the remnant cat population was not reproductively viable, i.e., Criterion 1 had actually been met but this was not known at the time.

Another Tasmanian island where an eradication of cats was attempted on a limited budget was Tasman Island, 29 $\mathrm{km}$ to the southeast of Wedge Island. Seven visits between 1977 and 1982 utilised shooting and 1080 baits to remove cats. Population reduction was being achieved and further visits planned (Brothers 1982). The final effort to remove the cats, believed to be very low in number (e.g., three or less) did not occur (N. Brothers pers. comm.), and highlights the importance of securing sufficient resources for eradication work. The remnant cat population unfortunately recovered rather than dying out but was finally eradicated in 2010 (Robinson et al. 2015).

The cats on Wedge Island fed primarily on seabirds because most other common prey species were not present (e.g. rats, House Mice or European Rabbits). In 1984, Brothers (1984) noted 13 adult Little Penguins killed and/or consumed by cats over 12 field days during July and August. Examination of cat scats between May and September 1995 (Beh 1995) had Short-tailed Shearwater as the most prevalent dietary item in May (prior to their northward migration) and Little Penguin increasing with a peak in July. Native Hen remnants were also present in smaller proportions throughout Beh's 1995 study period. Eggshell fragments in scats increased in July and were likely from the eggs of Native Hens or Little Penguins. Beh (1995) reports caterpillars (species not recorded) increasing in prevalence in cat diet from July to September. Little Penguins and Native Hens, with the addition of caterpillars, supported cats through the low-food months when Short-tailed Shearwaters were absent. Some of the adult cats captured in 2003 showed extreme wearing 
of teeth, suggesting items like intertidal limpets (Class Gastropoda) or mussels (Class Bivalvia) may have been prised from rocks and consumed.

The tabby coat colour of cats was not common on Wedge Island in 2003, with only two of 14 recorded with this pelage. It is feasible the tabby coloured cat observed in 2003, 2004 and 2010, and found dead in 2012, was in fact the same animal. This would give a minimum age of nine years at its death. From an ear-tattooed cat found in 2003, marked in the Beh (1995) study, it was known that cats on Wedge Island could live at least eight years. Interestingly, the cat coat colours recorded by Brothers in 1984 were mostly tabby (9 of 12 trapped) with others being tabby with a white front (2), white with black patches (1) or all black (1). Beh (1995) did not describe coat colours but provided a black and white image of a tabby or tortoiseshell cat with white legs and underparts.

\section{CONCLUSION}

Leaving individuals remaining on an island is not a recommended or desired outcome, but when island-based pest eradication work is undertaken on a very low budget, there can be higher risks to achieving success. Detecting survivors can be labour-intensive and costly, and projects may be left without sufficient funds. Fortunately for Wedge Island and its seabirds, the eradication of cats was eventually successful despite the presence of survivors. The primary knockdown left the remnant cat population, which could have been a single animal, so low that reproduction was impacted. This resulted in an unviable population that ultimately died out.

\section{ACKNOWLEDGEMENTS}

The authors thank the Marine Conservation Program staff (DPIPWE); Tasmanian Parks and Wildlife Service staff; S. Brookes, J. Cleeland, R. Gaffney, M. Holdsworth, M.
Johnston, B. Lazenby, M. Pauza, P. Vertigan and P. Marmion for their assistance. The authors are also grateful to T. Priestley for assistance with the figure and N. Brothers for providing additional information.

\section{REFERENCES}

Beh, J.C.L. 1995: The winter ecology of the feral cat, Felis catus (Linnaeus 1758), at Wedge Island, Tasmania. Unpublished BSc Honours thesis, University of Tasmania, Hobart.

Bomford, M. \& O'Brien, P. 1995: Eradication or control for vertebrate pests? Wildlife Society Bulletin 23: 249-255.

Brothers, N. 1982: Feral cat control on Tasman Island. Australian Ranger Bulletin 2: 9.

Brothers, N. 1984: Original field notebook 24/8/84 Wedge Island. NS2366/1/67 State Library of Tasmania Archives, Hobart.

Brothers, N., Pemberton, D., Pryor, H. \& Halley, V. 2001 Tasmania's Offshore Islands: Seabirds and other Natural Features. Tasmanian Museum and Art Gallery, Hobart, Tasmania: 643 pp.

Campbell, K. J., Harper, G., Algar, D., Hanson, C.C., Keitt, B. S. \& Robinson, S. 2011: Review of feral cat eradications on islands. In Veitch, C.R., Clout, M.N. \& Towns, D.R. (eds.): Island Invasives: Eradication and Management. Gland, Switzerland. Proceedings of the International Conference on Island Invasives, IUCN: 37-46.

Clout, M.N. \& Veitch, C.R. 2002: Turning the tide on biological invasion: the potential for eradicating invasive species. In Clout, M.N. \& Veitch, C.R. (eds.): Turning the Tide: The Eradication of Invasive Species. Gland, Switzerland and Cambridge, UK. Proceedings of the International Conference on Island Invasives, IUCN: 1-3.

Robinson, S.A. \& Copson, G.F. 2014: Eradication of cats (Felis catus) from subantarctic Macquarie Island. Ecological Management \& Restoration 15(1): 34-40.

Robinson, S., Gadd, L., Johnston, M. \& Pauza, M. 2015: Longterm protection of important seabird breeding colonies on Tasman Island through eradication of cats. Journal of Ecology New Zealand 39(2): 316-322.

Vertigan, C. 2010: The life-history of short-tailed shearwaters (Puffinus tenuirostris) in response to spatio-temporal environmental variation. Unpublished $\mathrm{PhD}$ thesis, University of Tasmania, Hobart.

(accepted 5 October 2020) 